\title{
Physicochemical, Heavy Metals and Phenolic Compounds Analysis of Libyan Honey Samples Collected from Benghazi during 2009-2010
}

\author{
Mohamed H. S. Ahmida ${ }^{*}$, Saleh Elwerfali ${ }^{1}$, Ali Agha ${ }^{1}$, Mohamed Elagori ${ }^{1}$, Nagwa H. S. Ahmida ${ }^{2}$ \\ ${ }^{1}$ Nutrition Department, Faculty of Public Health, Benghazi University, Benghazi, Libya; ${ }^{2}$ Environmental Health Department, Faculty \\ of Public Health, Benghazi University, Benghazi, Libya. \\ Email: "hamzasol@yahoo.com
}

Received August $30^{\text {th }}, 2012$; revised November $26^{\text {th }}, 2012$; accepted December $3^{\text {rd }}, 2012$

\begin{abstract}
In the present work, the results of analysis of 10 Libyan honey samples, representing various floral honeys, collected from Benghazi city during different seasons in 2009-2010 were demonstrated. All samples were examined for the physicochemical quality parameters, phenolic compounds and heavy metals contents. The moisture; optical density (O. D.); electrical conductivity; water insoluble solids; ash content; $\mathrm{pH}$; total acidity; hydroxylmethyl furfural (HMF); sugar contents and phenolic compounds content were detected according to AOAC 1990-Official Methods and reference methods. The results were compared with Libyan Standard Legislation and the European Standard Legislation. The obtained results indicated that the quality of the tested Libyan honey samples were very good and worth to the world standard properties of honey. Even more, the tested Libyan honey samples have high level of phenolic compounds content. On the basis of heavy metals content, three metals were determined (Cadmium, copper and lead) using atomic absorption spectrophotometer. The level of each metal-content was variable, which may be due to the conditions of processing, packing and storage conditions of Libyan honey samples.
\end{abstract}

Keywords: Libyan Honey; Physicochemical Parameters; Phenolic Compounds; Heavy Metals Contents

\section{Introduction}

Honey is defined as "the natural sweet substance produced by honey bees from nectar of blossoms or from secretions of living part of plants, which collected by honey bees". Then, they transform and combine their secretions with specific substances of their own, store and leave in honey comb to ripen and mature" [1-3].

Honey is produced in almost every country of the word and it has been consumed as a high nutritive and very important energy food. The importance of honey is coming from its composition of a complex mixture of carbohydrates and other minor substances, such as proteins; amino acids; organic acids; minerals and vitamins [4]. On other hand, honey cannot be considered as a completed food for human nutritional, but it offers potential as a dietary supplement [5].

Few studies were done about the Libyan honey; one of these studies was done by Owayes A. to determine the criteria of Libyan Eucalyptus honey. This study detected some of physicochemical properties, such as moisture; electrical conductivity; color; sugar content; total pro-

${ }^{*}$ Corresponding author. teins content and insoluble solids. This study was confirmed that the Eucalyptus Libyan honey has a very good quality. In other words, the results of this work were found within the limits set by Codex Alimentarius standard for honey and European Standard legislation [6].

The antibacterial activities of four types of Libyan honey were also examined [7]. This study observed that Libyan honey samples were affective against five species of human pathogenic bacteria isolated from burns. The antibacterial activities of honey samples were proportional to the honey samples concentrations.

In addition, El-Aaab M. E. and Al-Amrone A. Y. had demonstrated that the honey can be used as a marker for the environmental contamination by certain metals in some honey samples collected from different regions in the East of Libya [8]. The researchers in this study found that the concentrations of the metals such as cadmium, copper and lead were varied in the different honey samples, due to differences in honey types, the geographical regions and the weather of each region. They also found that all the collected honey samples were contaminated with cadmium and copper, because the concentrations of 
these metals were higher than limits set by Libyan legislations [8].

Since, there is no enough scientific published information about the quality and characteristic properties of Libyan honey.

This work aimed to determine the main quality criteria of various floral honey samples produced in Benghazi city, via estimating the typical physicochemical parameters as indicators of maturity, purity and also the content of some heavy metals as indicators for the environmental pollution.

\section{Experimental Part}

\subsection{Honey Samples}

Ten different samples of uniflora and multiflora Libyan honey (about $250 \mathrm{~g}$ for each) were collected during 20092010 seasons from beekeepers in Benghazi. The information concerning botanical data; location; local name and periods of collection were recorded in Table 1. These samples were placed in clean and dry glass bottles and kept at room temperature away from direct light until analysis.

Visually all honey samples showed no sign of fermentation or granulation before initiating the physicochemical analysis.

\subsection{Procedures}

\subsubsection{Physicochemical Analysis}

The samples of honey were analysed to determine moisture; optical density; specific gravity; electrical conductivity; water insoluble solids; ash content; $\mathrm{pH}$; total acidity; Hydroxymethyl furfural (HMF); sugar; polypheonls and heavy metals contents. All the chemicals and re- agents used in this work were of analytical grade.

Water content (moisture) of honey samples was determine according to AOAC method [9] by measuring the refractive index of honey using Bellingham and Stanley model Abbe-type refractometer.

Water insoluble solid contents in honey were determined by following Sigth N. and Bath P. K. method. The result expressed in percentages [10].

The specific gravity of honey samples were determined by dividing the weight of certain volume of honey sample to the weight of the same volume of water at constant temperature [10].

The Color of the honey samples was detected by measuring the optical density without honey dilution at 420 $\mathrm{nm}$, using a single beam Spectrophotometer (UV-VIS Spectrophotometer, SPECORD 40, Analytik Jena, Germany) [10].

The electrical conductivity of a solution containing 20 $\mathrm{g}$ honey in $100 \mathrm{~mL}$ distilled water is measured using an electrical conductive cell (Conductometer: Connet 2 Conductivity Meter with ATC-HANNA-Instruments). The conductance is read in $\mathrm{mS} / \mathrm{cm}$ after temperature equilibrium has been reached [11].

The ash content is obtained by ashing the honey at a high temperature, using electrical furnace and the ashing procedure is continued until constant weight is reached [9].

$\mathrm{pH}$, Free acidity and total acidity: the $\mathrm{pH}$ of honey samples was measured using $\mathrm{pH}$-meter (Ino lab WTW) equipped with glass combined electrode ( $p H$-electrode sen Tix 61-B023009AP017), in a solution prepared by dissolving $5 \mathrm{~g}$ of honey in a small volume of water, the solution is then quantitatively transferred to a $50 \mathrm{~mL}$ volumetric flask and filled to the mark with $\mathrm{CO}_{2}$-free distilled water [9].

Table 1. Ten types of libyan honey samples.

\begin{tabular}{|c|c|c|c|c|}
\hline Brand & Location & Honey type/floral source & Local name & Production period \\
\hline Sample 1 & Green Mountain & Ceratania siliqua & Elkharob & $1^{\text {st }}$ September- $31^{\text {st }}$ September \\
\hline Sample 2 & Green Mountain & Multiflora & Elrabee & $1^{\text {st }}$ March-3 $31^{\text {st }}$ September \\
\hline Sample 3 & Green Mountain & Arbutus pavari & Elhaoon & $15^{\text {th }}$ November- $30^{\text {th }}$ November \\
\hline Sample 4 & El-Abiar & Thymus capitatus & Elzaater & $15^{\text {th }}$ June- $30^{\text {th }}$ June \\
\hline Sample 5 & Benghazi & Eucalyptus & Elkafoor & $1^{\text {st }} \mathrm{July}-30^{\text {th }}$ August \\
\hline Sample 6 & Ejdabia & Eucalyptus & Elkafoor & $1^{\text {st }}$ July- $30^{\text {th }}$ August \\
\hline Sample 7 & Cyrene & Ziziphus lotus & Elseder & $15^{\text {th }}$ May- $15^{\text {th }}$ June \\
\hline Sample 8 & West Halls & Ziziphus lotus & Elseder & $15^{\text {th }}$ May- $15^{\text {th }}$ June \\
\hline Sample 9 & Emsalata & Thymus capitatus & Elzaater & $15^{\text {th }}$ June- $30^{\text {th }}$ June \\
\hline Sample 10 & South of Libya & Tamarix aphylla & Elatheal & $1^{\text {st }}$ July- $31^{\text {st }}$ July \\
\hline
\end{tabular}


The free acidity (F. A.) and total acidity (T. A.) of honey was determined by potentiometric titration method using $0.1 \mathrm{~N} \mathrm{NaOH}[9]$.

Sugar Content: reducing sugars (glucose, fructose) and apparent sucrose contents were determined by potentiometric titration using the Fehling's reagent [9].

Hydroxymethyl furfural (HMF) is determined by dissolving $5 \mathrm{~g}$ of honey sample in $25 \mathrm{~mL}$ dist. Water. The obtained solution is treated with a clarifying reagent $(0.5$ $\mathrm{mL}$ of $15 \%$ Potassium ferrocyanide and $30 \%$ Zinc acetate), then the volume is diluted to $50 \mathrm{~mL}$ with dist. water. The absorbance of the filtrated is measured at 284 and $336 \mathrm{~nm}$ against an aliquot of the filtrate treated with $5 \mathrm{~mL}$ $0.20 \%$ bisulphite solution. The HMF content (in $\mathrm{mg} / 100$ $\mathrm{g}$ honey) is calculated using Equation (1) [9].

$$
\mathrm{HMF}=((\text { A284 - A336) } /(\text { sample weight })) * 74.87
$$

The heavy metals content (cadmium, copper and lead) was determined using Atomic Absorption Spectrophotometer (AAS). $1 \mathrm{~g}$ of honey sample was placed in a small beaker and then $10 \mathrm{~mL}$ of concentrated nitric acid was added. The sample was heated on hot plate, until the evolving of brown fumes is stopped. $2.5 \mathrm{~mL}$ of hydrogen peroxide is added, and then the digest is transferred to $100 \mathrm{~mL}$ volumetic flask with deionized water. After centrifugation at $2000 \mathrm{rmps}$ for $5 \mathrm{~min}$, the solution is used to determine $\mathrm{Cd}, \mathrm{Cu}$ and $\mathrm{Pb}$ using AAS (Varian SpectAA-10 plus atomic absorption spectrophotometer equipped with a deuterium lamp for background correction and hollow-cathode lamps for each of the studied element), at appropriate wavelength (Table 2). The heavy metals content is determined using calibration curves of the different metal ions $(\mathrm{Cd}, \mathrm{Cu}$ and $\mathrm{Pb})$ [12].

The content of phenolic compounds in honey samples was assayed using Folin-Ciocalteu (F-C) reagent [13]. 20 $\mathrm{g}$ of honey is dissolved in $100 \mathrm{~mL}$ deionized water. 20 $\mu \mathrm{L}$ of the honey solution is then pipette into small tube and diluted with $1.58 \mathrm{~mL}$ water and mixed with $100 \mu \mathrm{L}$ of F-C reagent ( $2 \mathrm{~N}$ reagent available from sigma-Aldrich, Milan, Italy Company). The content of tube is mixed well using vortex mixer and allowed to react for $30 \mathrm{~min}$. Then $300 \mu \mathrm{L}$ of $20 \%(\mathrm{w} / \mathrm{v})$ sodium bicarbonate solution was added. After incubation for $30 \mathrm{~min}$ at $40^{\circ} \mathrm{C}$ the absorbance is measured at $276 \mathrm{~nm}$ against blank solution. The

Table 2. Conditions for individual metal for detection by AAS.

\begin{tabular}{ccc}
\hline Element & Wavelength $(\mathbf{n m})$ & Flame composition \\
\hline Cadmium & 228.8 & Air-acetylene \\
Copper & 324.7 & Air-acetylene \\
Lead & 217.0 & Air-acetylene \\
\hline
\end{tabular}

total phenolic content of each honey sample is obtained from the calibration curve prepared by standard solution of gallic acid. The total phenolic content is expressed as mg gallic acid/100 $\mathrm{g}$ of honey sample.

\section{Results and Discussion}

Tables 3-6 show the results, expressed as mean ( \pm s.d.) obtained from analysis of 10 Libyan honey samples (collected from the beekeepers in Benghazi city and harvested during 2009-2010 seasons). The tables included the results of physicochemical properties, sugar contents, levels of some heavy metals and phenolic compounds in ten libyan honey samples. The obtained data could were discussed and compared with the Libyan Standard legislation [14] as the following.

\subsection{Physicochemical Analysis}

Moisture content of the honey samples depends on the environmental conditions and the manipulation from beekeepers at the harvest period, and it can be changed from year to year [15]. Increases the moisture content of sample leads to decrease in its resistance against fermentation and also lead to crystallization in certain type of honey. Abu-Tarboush H. M. et al. reported that the moisture content of honey should be located in the $13.4 \%$ $18.0 \%$ range [16]. The moisture content of Libyan honey samples ranged from $13.3 \%$ (sample 5) to $17.2 \%$ (sample 7) (Table 3). In fact, the Libyan Standard Legislation required $\leq 17 \%$ of moisture content in the honey [14]. The moisture content of all Libyan honey samples are less than detectable limit except sample 7. However, the European Legislation required $\leq 20 \%$ moisture content in honey for safety against fermentation [2]. The level of moisture contents of Libyan honey samples indicates good ability of these samples.

The Specific gravity values, for the honey samples, ranged from 1.2081 to 1.2270 (Table 3). Although the specific gravity property has not legislated by the Libyan standard legislation and the European legislation [2,14], Singh N. and Bath P. K. mentioned that the variation in specific gravity may be attributed to the variation in chemical composition [10].

The electrical conductivity of honey samples depends on the contents of inorganic salts; organic acid; proteins; complex sugars and polyols, in addition to mineral contents [10]. The electrical conductivity of Libyan honey samples ranged $0.29-0.74 \mathrm{mS} / \mathrm{cm}$. These values are agreed with the limit sets by European Legislation $(<0.8$ $\mathrm{mS} / \mathrm{cm}$ ) [2], which indicated that all honey samples are from nectar honey [17].

Ash content of honey is depended on the flora type used and the material collected by bees. Ash content is a 
Table 3. Physicochemical parameters of ten samples of libyan honey.

\begin{tabular}{|c|c|c|c|c|c|c|c|c|c|c|}
\hline \multirow[t]{2}{*}{ Sample } & \multicolumn{10}{|c|}{ Parameters ${ }^{*}$} \\
\hline & $\begin{array}{c}\text { Moisture } \\
(\%)\end{array}$ & $\begin{array}{c}\mathrm{EC} \\
(\mathrm{mS} / \mathrm{cm})\end{array}$ & $\begin{array}{l}\text { Color } \\
\text { (O.D) }\end{array}$ & $\begin{array}{l}\text { Specific gravity } \\
\qquad\left(\mathrm{g} / \mathrm{cm}^{3}\right)\end{array}$ & $\begin{array}{c}\text { Insoluble water } \\
\text { solid (\%) }\end{array}$ & $\begin{array}{c}\text { Total ash } \\
(\%)\end{array}$ & $\begin{array}{l}\mathrm{HMF} \\
(\mathrm{mg} / \mathrm{kg})\end{array}$ & $\mathrm{pH}$ & $\begin{array}{c}\text { T. A. } \\
\text { (meq/kg) }\end{array}$ & $\begin{array}{c}\text { F. A. } \\
(\mathrm{meq} / \mathrm{kg})\end{array}$ \\
\hline Sample 1 & $14.3 \pm 1.10$ & $0.51 \pm 0.03$ & 1.339 & 1.2105 & 0.062 & $0.29 \pm 0.06$ & $1.89 \pm 0.35$ & $4.87 \pm 0.02$ & $18.0 \pm 1.0$ & $15.4 \pm 0.57$ \\
\hline Sample 2 & $16.4 \pm 0.75$ & $0.68 \pm 0.04$ & 1.465 & 1.2086 & 0.029 & $0.26 \pm 0.02$ & $3.48 \pm 0.23$ & $3.74 \pm 0.13$ & $18.0 \pm 1.5$ & $17.5 \pm 0.42$ \\
\hline Sample 3 & $16.1 \pm 0.95$ & $0.74 \pm 0.05$ & 2.509 & 1.2081 & 0.073 & $0.38 \pm 0.06$ & $5.90 \pm 0.27$ & $3.56 \pm 0.21$ & $22.0 \pm 0.5$ & $16.7 \pm 0.42$ \\
\hline Sample 4 & $16.8 \pm 0.45$ & $0.55 \pm 0.04$ & 0.666 & 1.2243 & 0.071 & $0.27 \pm 0.01$ & $8.24 \pm 0.56$ & $4.19 \pm 0.15$ & $20.5 \pm 1.5$ & $14.2 \pm 0.28$ \\
\hline Sample 5 & $13.3 \pm 1.55$ & $0.29 \pm 0.02$ & 1.054 & 1.2199 & 0.059 & $0.14 \pm 0.04$ & $2.93 \pm 0.68$ & $4.32 \pm 0.2$ & $20.0 \pm 2.0$ & $19.0 \pm 1.41$ \\
\hline Sample 6 & $15.6 \pm 0.85$ & $0.61 \pm 0.03$ & 1.584 & 1.2091 & 0.032 & $0.25 \pm 0.02$ & $3.71 \pm 1.11$ & $4.01 \pm 0.13$ & $16.0 \pm 1.0$ & $4.5 \pm 0.71$ \\
\hline Sample 7 & $17.2 \pm 0.30$ & $0.72 \pm 0.03$ & 0.867 & 1.2246 & 0.040 & $0.43 \pm 0.12$ & $7.09 \pm 1.45$ & $4.51 \pm 0.05$ & $10.0 \pm 3.0$ & $7.5 \pm 1.04$ \\
\hline Sample 8 & $15.5 \pm 0.35$ & $0.47 \pm 0.06$ & 0.809 & 1.2270 & 0.061 & $0.23 \pm 0.01$ & $2.71 \pm 0.59$ & $4.99 \pm 0.04$ & $24.0 \pm 1.0$ & $19.0 \pm 0.41$ \\
\hline Sample 9 & $16.5 \pm 0.75$ & $0.49 \pm 0.01$ & 1.707 & 1.2210 & 0.041 & $0.24 \pm 0.04$ & $4.68 \pm 0.74$ & $4.58 \pm 0.38$ & $20.0 \pm 1.5$ & $16.0 \pm 1.62$ \\
\hline Sample 10 & $16.7 \pm 0.63$ & $0.43 \pm 0.07$ & 0.937 & 1.2162 & 0.064 & $0.17 \pm 0.02$ & $3.51 \pm 1.19$ & $4.94 \pm 0.06$ & $18.0 \pm 1.5$ & $13.5 \pm 0.7$ \\
\hline $\begin{array}{l}\text { Libyan Standard } \\
\text { legislation }\end{array}$ & $\leq 17 \%$ & - & - & - & $\leq 0.1 \%$ & $\leq 1 \%$ & $<40 \mathrm{mg} / \mathrm{kg}$ & - & $<50 \mathrm{meq} / \mathrm{kg}$ & - \\
\hline
\end{tabular}

${ }^{*}$ Mean (two value) \pm sd.

Table 4. Analysis of sugar contents of libyan honey samples.

\begin{tabular}{ccc}
\hline Parameter & Min-max & Mean \pm sd \\
\hline Fructose & $33.89-45.04$ & $38.74 \pm 3.14$ \\
Glucose & $24.80-38.26$ & $32.6 \pm 4.38$ \\
Libyan standard legislation & Reducing sugar $>65 \%$ \\
Sucrose & $1.00-5.35$ & $2.97 \pm 0.89$ \\
Libyan standard legislation & \multicolumn{2}{c}{$<5 \%$} \\
\hline
\end{tabular}

quality criterion for honey botanical origin $[10,16]$. The ash content in different Libyan honey samples were different widely and ranging from $0.14 \%$ to $0.43 \%$. Sample 7 has the highest ash content $(0.43 \%)$ when compared with the other samples. The ash content of the Libyan honey samples fell with the requirement of Libyan legislation for honey $(<1 \%)$ These results indicated the clearness of honey samples and possibly lack of adulteration with molasses [5].

The water insoluble solid content represents the suspension wax particles, insect or vegetable debris [18]. The water insoluble content of all sample are below the limit sets at $0.1 \%$ by Libyan Legislation.

The $\mathrm{pH}$ values of the sample were low and ranged from 3.56 to 4.99 (Table 3). All samples were acidic and reflect the ability of honey to inhibit the presence and growth of microorganisms. As the maximum limit for $\mathrm{pH}$ value of honey had set at 5 [1], however, all samples full within this regulation. The content of total acidity of honey is due to the presence of organic acids particularly the gluconic acid and its ester or lactone forms, in addition to the presence of inorganic ions such as phosphate and chloride ions [19]. The low value of total acidity indicates the absence of undesirable fermentation. For the honey samples under investigation, sample 3 shows the highest value of total acidity $(24 \mathrm{meq} / \mathrm{kg})$ and sample 7 shows the smallest value $(10 \mathrm{meq} / \mathrm{kg})$. These total acidity values for the Libyan honey samples were not excessed the limits set by Libyan Standard Legislation and European legislation $(\leq 50 \mathrm{meq} / \mathrm{kg}) \quad[2,14]$. High acidity can be indicative of fermentation of sugars into organic acids.

HMF content is formed via dehydration of hexose sugars in acid medium [10,20]. Several factors, such as temperature; time of heating during processing; storage conditions; aging of honey product and sources of flora, were found to influence the HMF content in honey [17]. HMF provides an indication to the degree of freshness of honey $[6,17]$, overheating and storaging in poor conditions [21]. The legal regulation of Libyan honey sample sets a maximum $\mathrm{HMF}$ of $40 \mathrm{mg} / \mathrm{kg}$, meanwhile, the maximum level limit sets by European legislation [2] is $80 \mathrm{mg} / \mathrm{kg}$. All honey samples have HMF content values lower than the maximum limit sets by both Libyan standard legislation and European legislations (Table 3). The low levels of HMF in Libyan honey samples indicate a high degree of freshness.

The color of honey samples varied from light to dark yellow. Several publications mention that the honey 
Table 5. Analysis of metal ions in ten types of Libyan honey.

\begin{tabular}{ccccc}
\hline Type & $\begin{array}{c}\text { Cd } \\
(\mathrm{mg} / \mathrm{Kg})\end{array}$ & $\begin{array}{c}\mathbf{C u} \\
(\mathrm{mg} / \mathrm{Kg})\end{array}$ & $\begin{array}{c}\text { Pb } \\
(\mathrm{mg} / \mathrm{Kg})\end{array}$ & $\begin{array}{c}\text { Total metal } \\
\text { content }\end{array}$ \\
\hline Sample 1 & N. D. & 6.60 & 0.02 & 6.62 \\
Sample 2 & 0.005 & 10.40 & 0.06 & 10.465 \\
Sample 3 & 0.004 & 9.90 & N. D. & 9.904 \\
Sample 4 & N. D. & 2.70 & N. D. & 2.700 \\
Sample 5 & N. D. & 6.10 & N. D. & 6.100 \\
Sample 6 & N. D. & 7.80 & N. D. & 7.800 \\
Sample 7 & N. D. & 3.50 & 0.03 & 3.530 \\
Sample 8 & N. D. & 4.20 & N. D. & 4.200 \\
Sample 9 & N. D. & 0.80 & N. D. & 0.800 \\
Sample 10 & N. D. & 3.20 & N. D. & 3.200 \\
\hline
\end{tabular}

${ }^{*}$ N. D. = non detected (less than the instrument sensitivity.

Table 6. Total phenolic contents of ten Libyan honey samples.

\begin{tabular}{cc}
\hline Type & Phenolic content (mg Gallic acid/100g sample) \\
\hline Sample 1 & $91.0 \pm 2.12$ \\
Sample 2 & $90.25 \pm 1.77$ \\
Sample 3 & $58 \pm 2.83$ \\
Sample 4 & $81.0 \pm 2.21$ \\
Sample 5 & $72.25 \pm 3.89$ \\
Sample 6 & $49.0 \pm 2.21$ \\
Sample 7 & $94.0 \pm 2.21$ \\
Sample 8 & $67.8 \pm 3.18$ \\
Sample 9 & $60.5 \pm 1.41$ \\
Sample 10 & $68.25 \pm 1.77$ \\
\hline
\end{tabular}

color depends on various factors, being the mineral content; ash content [22-24] and active pigments such as carotenoids and flavonoids [23,24]. Singh N. and Bath P. $\mathrm{K}$. reported that HMF content in honey corroborated well with the color value measured as Optical Density (O. D.) at $420 \mathrm{~nm}$ [10]. Different procedures were used to measure the O. D. and color of the honey. Gomes S. et al. have classified the color of honey according to Pfund scale [17]. In the other hand, Owayss A. was measure the O. D. of honey by measuring the absorbance of filtrate supernatant of $10 \%$ honey sample (in dist. Water) at 530 [6]. The O. D. of the Libyan honey samples ranged from 0.666 to 2.509 (Table 3).

Reducing sugars, mainly fructose and glucose, represented the largest portion of honey composition. The summation of the percentages of fructose and glucose contents gives values above $65 \%$ (the minimum limit sets by both Libyan Standard Legislation and European legislation in all Libyan honey samples under investigation (Table 4) $[2,14]$. Non-reducing sugars (apparent sucrose) are set to be $\leq 5 \%$ by Libyan Standard Legislation. High sucrose contents could be the result of an early harvest of honey, as the sucrose has not been converted to fructose and glucose [25]. In our case, the levels of sucrose for all Libyan honey samples under investigation are less than 5\% (Table 4).

\subsection{Metal Content Analysis}

As the Libyan Standard Legislation for honey does not set a maximum limits for the presence of metals in honey, so noticeable contents of heavy metals means contamination with these metals. In this work, Metals such as cadmium, copper and lead were analyzed in all honey samples (Table 5).

The presence of cadmium in Libyan honey samples gives an indication of contamination probably from the processing equipments. All Libyan honey samples under investigation were free from cadmium except sample 2 and sample 3. According to the maximum limit for cadmium content sets by European Legislation $(0.1 \mathrm{mg} / \mathrm{kg})$, all Libyan honey samples were free from cadmium metal contamination [2].

Lead was detected in sample $1(0.02 \mathrm{mg} / \mathrm{kg})$, sample 2 $(0.06 \mathrm{mg} / \mathrm{kg})$ and sample $7(0.03 \mathrm{mg} / \mathrm{kg})$. According to the Libyan Standard Legislation, these three samples were contaminated with Lead. However, these levels were less than the maximum limit sets by European Legislation $(1 \mathrm{mg} / \mathrm{kg})$ for lead in honey.

Copper is one of the essential metals that present in small amount in honey. It is not toxic if it is present in a limited amount. Although Libyan Standard Legislation of honey recommended the absence of copper metal, it was detected in all honey samples. Its concentration was ranging from $0.80 \mathrm{mg} / \mathrm{kg}$ (sample 9) to $10.40 \mathrm{mg} / \mathrm{kg}$ (sample 2). Italian legislation [26] for the presence of copper metal in honey sets a limit at $0.216 \mathrm{mg} / \mathrm{kg}$. According to Italian legislation, all the honey samples under investigation were contaminated. This contamination of copper may be come from pesticides or from water that kept in containers made of copper metal. In other hand, the Nigerian regulations [11] has set a limit of $35 \mathrm{mg} / \mathrm{kg}$ for the presence of copper-metal content in honey sample, that's mean that copper metal contents of Libyan honey samples much lower than this permissible limit.

\subsection{Phenolic Components Analysis}

Honey is known to be rich in both enzymetic and 
non-enzymentic antioxidants including: glucose oxidase, catalase, ascorbic acid, flavonoids, phenolic acid, carotenoid derivative, organic acid, amino acid and proteins. Beretta G. et al. reported that the content of phenolic acids in various honey types ranged at level of $6.7-79.0$ $\mathrm{mg}$ gallic acid/100g of hone and honey samples from strawberry tree contain the highest phenolic content and antioxidant activity [27].

The total phenolic content was determined in Libyan honey samples by a modification of Sangrichan S. and Wanson W. method [13]. The total phenolic contents were found in the range of 49.0 to $94.0 \mathrm{mg}$ gallic acid/ $100 \mathrm{~g}$ sample (Table 6), indicating that Libyan honey samples have high phenolic contents and high antioxidant activity.

\subsection{Correlation between the Physicochemical Parameters}

Table 7, shows the correlations between physicochemical parameters for the Libyan honey samples under study. A positive correlation between electrical conductivity and total ash content is obtained. This correlation was reported by Piazza M. G. et al. who has used the Equation (2) to calculate electrical conductivity values of honey samples using the values of ash content [28].

$$
\text { Conductivity }=1.74 \times \text { Ash content }(\%)+0.14
$$

The values of electrical conductivity either experimentally measured and calculated values were shown in Table 8. The comparison between these values gives low relative error $(\mathrm{Er}<20)$ except for sample 1,5 and 7. Oways A. recommended that ash content could be kept a quality factor during a transition period, until conductivity is accepted as a word wide standard [6].

A positive correlation was also obtained between specific gravity and heavy metal contents. Although specific gravity has not legislated by the alimentary standard regulation committee in the world, so this correlation should take into account for further study.

\section{Conclusion}

The physicochemical analysis of the honey samples under investigation generally agree with national and international honey legislation, which indicated that the honey samples were of good quality and had acceptable value of maturity, purity, cleanness and freshness.

Analysis of heavy metal contents indicated that the all honey samples were contaminated with copper, as well as few sample were contaminated with cadmium and lead.

Table 7. Matrix of the correlation between analysed parameters for the libyan honey samples.

\begin{tabular}{|c|c|c|c|c|c|c|c|c|c|c|c|}
\hline \multicolumn{12}{|l|}{ Parameters ${ }^{*}$} \\
\hline & $\begin{array}{c}\text { Moisture } \\
(\%)\end{array}$ & $\begin{array}{c}\mathrm{EC} \\
(\mathrm{mS} / \mathrm{cm})\end{array}$ & O.D. & $\begin{array}{l}\text { Specific } \\
\text { gravity } \\
\left(\mathrm{g} / \mathrm{cm}^{3}\right)\end{array}$ & $\begin{array}{l}\text { Insoluble } \\
\text { water } \\
\text { solid (\%) }\end{array}$ & $\begin{array}{c}\text { Total ash } \\
(\%)\end{array}$ & $\begin{array}{c}\mathrm{HMF} \\
(\mathrm{mg} / \mathrm{kg})\end{array}$ & $\mathrm{pH}$ & $\begin{array}{c}\text { T. A } \\
(\mathrm{meq} / \mathrm{kg})\end{array}$ & $\begin{array}{l}\text { Heavy metal } \\
\text { contents } \\
(\mathrm{ppm})\end{array}$ & $\begin{array}{c}\text { Phenolic } \\
\text { compounds } \\
\text { content }\end{array}$ \\
\hline Moisture (\%) & - & 0.370 & & & & & & & & & \\
\hline $\mathrm{EC}$ & 0.374 & - & & & & & & & & & \\
\hline O. D. $((\mathrm{mS} / \mathrm{cm})$ & 0 & 0.201 & - & & & & & & & & \\
\hline $\begin{array}{l}\text { Specific gravity } \\
\qquad\left(\mathrm{g} / \mathrm{cm}^{3}\right)\end{array}$ & 0.027 & 0.131 & 0.510 & - & & & & & & & \\
\hline $\begin{array}{l}\text { Insoluble water } \\
\text { solid }(\%)\end{array}$ & 0.036 & 0.083 & 0.004 & 0.036 & - & & & & & & \\
\hline HMF (mg/kg) & 0.446 & 0.245 & 0.003 & 0.110 & 0.020 & 0.322 & - & & & & \\
\hline $\mathrm{pH}$ & 0.015 & 0.343 & 0.376 & 0.304 & 0.038 & 0.102 & 0.135 & - & & & \\
\hline T. A (meq/kg) & 0.082 & 0.021 & 0.265 & 0.270 & 0.170 & 0.156 & 0.017 & 0.214 & & & \\
\hline $\begin{array}{l}\text { Heavy metals } \\
\text { content (ppm) }\end{array}$ & 0.079 & 0.185 & 0.311 & 0.642 & 0.022 & 0.031 & 0.077 & 0.473 & 0.099 & - & \\
\hline $\begin{array}{l}\text { Phenolic } \\
\text { compounds } \\
\text { content }\end{array}$ & 0.004 & 0.019 & 0.222 & 0.030 & 0.003 & 0.086 & 0.011 & 0.029 & 0.492 & 0.001 & - \\
\hline
\end{tabular}

${ }^{*}$ Values of correlation coefficient $\left(\mathrm{r}^{2}\right)$. 
Table 8. Correlation between electrical conductivity and ash content for the libyan honey samples.

\begin{tabular}{|c|c|c|c|}
\hline Type & Real value of $\mathbf{E C}^{\mathrm{a}} \mathrm{mS} / \mathrm{cm}$ & Calculated value of $\mathbf{E C}^{\mathbf{b}} \mathrm{mS} / \mathrm{cm}$ & Relative error (\%) \\
\hline Sample 1 & 0.51 & 0.64 & -25.5 \\
\hline Sample 2 & 0.68 & 0.59 & 13.24 \\
\hline Sample 3 & 0.74 & 0.80 & -8.11 \\
\hline Sample 4 & 0.55 & 0.60 & -9.09 \\
\hline Sample 5 & 0.29 & 0.38 & 31.03 \\
\hline Sample 6 & 0.61 & 0.58 & 4.92 \\
\hline Sample 7 & 0.72 & 0.89 & -23.6 \\
\hline Sample 8 & 0.47 & 0.54 & 0.15 \\
\hline Sample 9 & 0.49 & 0.56 & -0.00 \\
\hline Sample 10 & 0.43 & 0.44 & -0.00 \\
\hline
\end{tabular}

${ }^{\mathrm{a}} \mathrm{EC}$ is the measured electrical conductivity. ${ }^{\mathrm{b}}$ The values of $\mathrm{EC}$ calculated using equation $2 .{ }^{\mathrm{c}}$ Error $\%=($ real value - calc. value $) /($ real value $) \times 100$.

The Libyan Standard Legislation 1995 not been legislated some of important criteria for honey such as $\mathrm{pH}$, electrical conductivity, level of heavy metals contents.

\section{REFERENCES}

[1] Codex Alimentarius Commission, "Revised Codex Standard for Honey Codex Stan 12-1981, Rev. 1 (1987), Rev. 2 (2001)," Codex Standard, Vol. 12. 1981, pp. 1-7. http://teca.fao.org/sites/default/files/resources/Annex\%20 A\%20Codex\%20Alimentarius\%20Honey\%20Standard.p df

[2] The Council Of The European Union, "Council Directive 2001/110/EC of 20 December 2001 Relating to Honey," Official Journal of the European Communities, Vol. L10, 2002, pp. 47-52.

http://eurlex.europa.eu/LexUriServ/LexUriServ.do?uri=O J:L:2002:010:0047:0052:EN:PDF

[3] E. Anklam, "A Review of the Analytical Methods to Determine the Geographical and Botanical Origin of Honey," Food Chemistry, Vol. 63, No. 4, 1998, pp. 549-562. doi:10.1016/S0308-8146(98)00057-0

[4] J. W. White, "Composition of Honey," In: E. Crane, Ed., Honey: A Comprehensive Survey, Heinemann, London, 1975, pp. 157-206.

[5] E. Mendes, E. B. Proenca, I. M. Ferreira and M. A. Ferreira, "Quality Evaluation of Portuguese Honey," Carbohydrate Polymers, Vol. 37, No. 3, 1998, pp. 219-223. doi:10.1016/S0144-8617(98)00063-0

[6] A. Owayss, "Physicochemical Analysis for Standardizing Quality Criteria of Libyan Eucalyptus Honey," Egyptian Journal of Applied Science, Vol. 20, No. 6, 2004, pp. 247-255.

[7] A. El-Amari and S. Ben-Gweirif, "In Vitro Study of Antibacterial Activities of Some Libyan Honey against Bacteria Isolated from Burns," 2006.

http://garyounis.edu/sci/gsfs/chapter3/pdf
[8] M. E. El-Aab and A. Y. Al-Amrony, "Use of Honey as a Marker for Enviromental Contamination with Heavy Metals in East Libyan Regions," 2009. http://www.Saudibi.com/49.doc

[9] AOAC, "Association of Official Analytical ChemistryOfficial Methods of Analysis," AOAC, Arlington, 1990.

[10] N. Singh and P. K. Bath, "Quality Evaluation of Different Types of Indian honey," Food Chemistry, Vol. 58, No. 1-2, 1997, pp. 129-133. doi:10.1016/S0308-8146(96)00231-2

[11] F. Adebiyi, I. Akpan, E. I. Obiajunwa and H. B. Olaniyi, "Chemical and Physical Characterization of Nigerian Honey," Pakistan Journal of Nutrition, Vol. 3, No. 5, 2004, pp. 278-281. doi:10.3923/pjn.2004.278.281

[12] A. M. G. Paramas, J. A. G. Barez, R. J. Garcia-Villanova, T. R. Pala, R. A. Albajar and J. S. Sanchez, "Geographical Discrimination of Honeys by Using Minerals Composition and Common Chemical Quality Parameters," Journal of the Science of Food and Agriculture, Vol. 80, No. 1, 2000 , pp. 157-165. doi:10.1002/(SICI)1097-0010(20000101)80:1<157::AIDJSFA506>3.0.CO;2-B

[13] S. Sangrichan and W. Wanson, "Antioxidant Capacity of Honey Samples Collected in The North Part of Thialand in Relationship with Total Polyphenols," KMITL Science Journal, Vol. 8, No. 2, 2008, pp. 68-73.

[14] Libyan National Center for Standardization and Metrology, Ministry of Commerce, "Libyan Standard Concerning Honey," Libyan Standard Legislation for Industrial and Non Industrial Food, Concerning Honey, No. 281, 1995, pp. 47-52.

[15] C. Acquarone, P. Burera and B. Elizalde, "Patter of $\mathrm{pH}$ and Electrical Conductivity upon Honey Dilution as a Complementary Tool for Discrimination Geographical Origin of Honeys," Food Chemistry, Vol. 101, No. 2, 2007, pp. 695-703. doi:10.1016/i.foodchem.2006.01.058

[16] H. M. Abu Tarboush, H. A. Al-Kahtani and M. S. A. 
Ellsarrag, "Floral-Type Identification and Quality Evaluation of Some Honey Types," Food Chemistry, Vol. 46, No. 1, 1993, pp. 13-17.

doi:10.1016/0308-8146(93)90068-Q

[17] S. Gomes, L. G. Dias, L. L. Moreira and P. Rodrigues, "Physicochemical, Mirobiological and Antimicrobial Properties of Commercial Honeys from Portugal," Food and Chemical Toxicology, Vol. 48, No. 2, 2010, pp. 544548. doi:10.1016/j.fct.2009.11.029

[18] P. E. W. Rodgers, "Honey Quality Control," In: E. Crane, Ed., Honey: A Comprehensive Survey, Heinemann, London, 1975, pp. 314-325.

[19] T. Echigo and T. Tukenaka, "Production of Organic Acids in Honey by Honeybees," Journal of the Agricultural Chemical Society of Japan, Vol. 48, 1974, pp. 225-230.

[20] S. Hanse, O. Suzuki, M. Odate and S. Suzuki, "Change in Quality of Honey on Heating and Storage I. Changes in Hydroxymethyl Furfural (HMF) Content of Honey," Journal of the Agricultural Chemical Society of Technology, Vol. 20, 1973, pp. 248-256.

[21] B. Fallico, E. Arena, A. Verzera and M. Zappala, "The European Food Legislation and Its Impact on Honey Sector," Accreditation and Quality Assurance, Vol. 11, No. 1-2, 2006, pp. 49-54. doi:10.1007/s00769-006-0128-6

[22] M. L. Al, D. Danel, A. Moise, O. Bobis, L. Lasio and S. Bondanov, "Physicochemical and Bioactive Properties of Different Flora Origin Honeys from Romania," Food Chemistry, Vol. 112, No. 4, 2009, pp. 863-867. doi:10.1016/j.foodchem.2008.06.055

[23] J. Bertoncelj, U. Dobersek, M. Jamnik and T. Gdob,
"Evaluation of the Phenolic Content, Antioxidant Activity and Color of Slovenian Honey," Food Chemistry, Vol. 105, No. 2, 2007, pp. 822-828. doi:10.1016/j.foodchem.2007.01.060

[24] L. Yao, Y. Jians, R. D. Singanusong, B. Arcy, N. Datta, N. Caffin and K. Ray, "Flavonoids in Australian Melaleuca, Guioa, Lophostemon, Banksia and Helianthus Honeys and their Potential for Flora Authentication," Food Research International, Vol. 37, No. 2, 2004, pp. 166-174. doi:10.1016/j.foodres.2003.11.004

[25] L. C. Azeredo, M. A. A. Azeredo, S. R. Souza and V. M. L. Dutra, "Protein Contents and Physicochemical Properties in Honey Samples of Apis Mellifera of Different Floral Origen," Food Chemistry, Vol. 80, No. 2, 2003, pp. 249-254. doi:10.1016/S0308-8146(02)00261-3

[26] S. Caroli, G. Forte, A. L. Lamiceli and B. Galoppi, "Determination of Essential and Potentially Toxic Trace Element in Honey by Inductively Coupled Plasma-Based Techniques," Talanta, Vol. 50, No. 2, 1999, pp. 327-336. doi:10.1016/S0039-9140(99)00025-9

[27] G. Beretta, P. Granata, M. Ferrero, M. Orioli and R. Maffei Facino, "Standardization of Antioxidant Properties of Honey by a Combination of Spectrophotometric/Fluorimetric Assays and Chemometrics," Analytica Chimica Acta, Vol. 533, No. 2, 2005, pp. 185-191. doi:10.1016/j.aca.2004.11.010

[28] M. G. Piazza, M. Accorti and L. Persano-Oddo, "Electrical Conductivity, Ash, Color and Specific Rotator Power in Italian Unifloral Honeys," Apicultora, Vol. 7, 1991, pp. 51-63. 